\title{
HAK HADHANAH DALAM PUTUSAN PENGADILAN AGAMA
}

\author{
Elimartati ${ }^{1}$, Firdaus ${ }^{2}$ \\ 1 Fakultas Syariah IAIN Batusangkar \\ e-mail: elimartati2013@gmail.com \\ 2 Fakultas Syariah IAIN Batusangkar \\ e-mail: almuqaddasfirdaus@gmail.com
}

\begin{abstract}
The purpose of the research is to reveal the rights of custody of children that have not been mumajiz if there is a divorce seen from the requirements set by the ulama in Islamic law or the benefit of the child. Today's condition often happens to mothers or apostates who cause divorce, or the condition of mothers who have divorced their husbands as career women. Does it have implications for hadhanah rights for mothers or fathers? The normative qualitative approach was applied in this study. The results of the discussion of the four cases decided by the Religious Court which became the object of research gave foster rights (hadhanah) to fathers because fathers have competence in child care, such as having good moral, having competence in the science of education and social competence that is responsible and prioritizes the benefit of children from to determine the rights of mothers as child care. In this condition the father fulfills the requirements of the hadhin compared to the mother.
\end{abstract}

Kata kunci: Hadhanah, Realita, Kemaslahatan

\section{PENDAHULUAN}

Znak pada permulaan hidupnya sampai $\mathcal{A}_{\text {umur tertentu memerlukan orang lain }}$ dalam kehidupannya yang disebut dengan pengasuhan (hadhanah). Seseorang yang melakukan tugas hadhanah dalam hukum Islam mempunyai syarat-syarat tertentu (Sayyid Sabiq, 1984: 160). Keutuhan dan kerukunan rumah tangga merupakan dambaan setiap keluarga tetapi realitasnya pada masyarakat saat ini banyak terjadi perceraian. Sebagai ilustrasi data laporan Pengadilan Agama Batusangkar tahun 2017 terdapat surat permohonan cerai talak berjumlah 166 perkara dan cerai gugat 400 serta penguasaan anak 6 perkara. (PA Batusangkar, 2017). Bila terjadi perceraian timbul pertanyaan siapa yang berhak mengasuh anak (hadahanah). Hukum Islam mengutamakan ibu dalam pengasuhan bila terjadi perceraian (Hadis dalam Abud Dawud 2244 dan An-Nasa'i 3495, n.d.). Dilihat dari kedudukan ibu dalam suatu kasus terjadi seorang ibu yang murtad dan juga terjadi kesibukkan di luar rumah apakah yang diutamakan ibu sebagai perempuan karir atau tidak terpenuhi syarat beragama Islam (Satria Effendi, 2004: 166). Dilihat dari syarat seorang hadin terdapat perbedaan pendapat para fuqaha tentang syarat beragama Islam dalam hak asuh (ibu yang murtad) (Wahbah Az-zuhaily, 2011: 50). Dalam suatu kasus terjadi perceraian yang isteri berpindah agama dan dia juga sebagai perempuan karir yang sibuk di luar rumah. Dalam hal ini dipertanyakan siapa yang berhak terhadap pengasuhan 
anak, apa alasan yang dijadikan dasar penetapan yang berhak mengasuh anak. Apakah persyaratan agama atau ketersediaaan waktu dari hadhin untuk melaksanakan pengasuhan. Penetapan hadhanah apakah dilihat dari persyaratan hadhin yang ditetapkan oleh hukum Islam atau kemaslahatan untuk memenuhi kebutuhan anak.

Kondisi anak saat sekarang sangat memprihatinkan. Dilihat dalam lingkup rumah tangga. Anak banyak mendapat kekerasan dalam rumah tangga secara fisik, psikhis, pelecehan dari orang terdekat dan penelantaran rumah tangga. Laporan Komisi Nasional Perlindungan mendapatkan kasus berjumlah 2.373 kasus (Tribun news, 2017). Permasalahan di atas akan dicoba menganalisisnya berdasarkan hukum Islam, dengan pendekatan problem solving yang ditemukan dalam masyarakat keseharian. Anak yang jadi obyek penelitian adalah anak yang berumur di bawah 9 atau 10 tahun yang belum mumajiz atau anak yang berkebutuhan khusus (disabilitas).

\section{METODE PENELITIAN}

Penelitian ini merupakan pranata sosial yang berkaitan dengan yuridis formal. Metode yang dipakai adalah kualitatif, dengan pendekatan hukum normatif. Penelitian bersifat conten analisis yang bersumber dari putusan pengadilan, yuris prodensi dan peraturan yang terakit dengan masalah yang diteliti, dan buku-buku hukum. Penelitian mengununakan sumber data sekunder. Data sekunder ini dibagi menjadi bahan hukum primer adalah buku fikih, Undang-Undang dan Yuris prodensi. Bahan hukum sekunder hasil penelitian, Jurnal dan lain-lain. Bahan hukum tersier merupakan bahan pendukung berupa kamus, ensiklopedi dan lain-lain. Mendudukkan masalah hukum tentang hadhanah dilakukan dengan memakai metode istinbath hukum yaitu menetapkan hukumnya berdasarkan ayat-ayat Alqur'an, Hadis-hadis Rasulullah SAW. yang menjadi dasar hukum dari masalah yang ditetapkan hukumnya. Mengambil kaedah dalil-dalil di atas. Dalam hal yang belum jelas hukumnya ditetapkan berdasarkan dalil di atas, maka melihat dalil- dalil hukum yang dipakai para ulama dalam men-istinbath-kan hukum.

\section{PEMBAHASAN}

1. Pengertian Hadhanah

Hadhanah mashdar dari kata hadhnuash-shabiy, atau mengasuh atau memelihara anak. Mengasuh (hadhn) dalam pengertian ini tidak dimaksudkan dengan menggendongnya di bagian samping dan dada atau lengan. Pengertian secara syara' hadhanah artinya pemeliharaan anak bagi orang yang berhak untuk memeliharanya. Bisa juga diartikan memelihara atau menjaga orang yang tidak mampu mengurus kebutuhannya sendiri kerena tidak mumayyiz seperti anak-anak, orang dewasa tetapi gila. Pemeliharaan di sini mencakup urusan makanan, pakaian, urusan tidur, membersihkan, memandikan, mencuci pakaian, dan sejenisnya. (Wahbah Az-zuhaily, 2011: 59). Hadhanah merupakan mendidik orang yang tidak dapat mengurus dirinya sendiri dengan apa yang bermaslahat baginya dan memeliharanya dari apa yang membahayakan meskipun orang itu 
telah dewasa, (Wahbah Az-zuhaily, 2011: 60) apabila sesorang mempunyai kebutuhan khusus seperti cacat atau idiot (disabilitas).

Penekanan pengasuhan (hadhana) dalam penulisan ini adalah kepada anak yang belum mumayiz, artinya anak di bawah umur 9 atau sepuluh tahun.

2. Pengasuhan terhadap anak

Hadhanah yang di maksud dalam hal ini adalah kewajiban orang tua untuk memelihara dan mendidik anak mereka dengan sebaik-baiknya yang mencakup masalah ekonomi, pendidikan dan segala sesuatu yang menjadi kebutuhan pokok si anak. Beranjak dari ayat-ayat Alquran seperti dalam surah Luqman ayat 1219 , ada 8 nilai-nilai pendidikan yang harus diajarkan orang tua kepada anaknya yaitu: Agar senantiasa mensyukuri nikmat Allah SWT, tidak mensyarikatkan Allah dengan sesuatu yang lain, berbuat baik kepada orang tua, sebagai bukti kesyukuran anak, mempergauli orang tua secara baikbaik (ma'ruf), setiap perbuatan betapapun kecilnya akan mendapatkan balasan dari Allah SWT, menaati perintah Allah SWT, tidak sombong dan angkuh, sederhana dalam bersikap dan bertutur kata (akhlak mulia).

Proses pemeliharaan anak dan pendidikannya akan dapat berjalan dengan baik, jika kedua orang tua saling bekerja sama dan saling membantu. Tentu saja dapat dilakukan dengan baik jika keluarga tersebut benar-benar keluarga yang sakinah dan mawaddah. Kewajiban dan tanggung jawab keluarga (orang tua) terhadap anak dijelaskan dalam (Undang Undang Nomor: 23 tahun 2002 tentang perlindungan anak yang telah diubah dengan Undang Undang Nomor: 35 tahun 2014, n.d.) Pasal 26 bahwa:

a. Orang tua berkewajiban dan bertanggung jawab untuk:

1) mengasuh, memelihara, mendidik dan melindungi anak;

2) menumbuhkembangkan anak sesuai dengan kemampuan, bakat, dan minatnya;

3) mencegah terjadinya perkawinan pada usia anakanak.

b. Dalam hal orang tua tidak ada, atau tidak diketahui keberadaannya, atau karena suatu sebab, tidak dapat melaksanakan kewajiban dan tanggung jawabnya, maka kewajiban dan tanggung jawab sebagaimana dimaksud dalam ayat (1) dapat beralih kepada keluarga, yang dilaksanakan sesuai dengan ketentuan peraturan perundangundangan yang berlaku.

(Undang-Undang Nomor 1 Tahun 1974 Tentang Perkawinan, 1974)Nomor 1 Tahun 1974 tentang Perkawinan Pasal 45 menyebutkan bahwa (1) Kedua orang tua wajib memelihara dan menddidik anakanak mereka sebaik-baiknya (2) Kewajiban orang tua yang dimaksud dalam ayat (1) pasal ini berlaku sampai anak itu kawin atau dapat berdiri sendiri kewajiban mana berlaku terus meskipun perkawinan antara kedua orang tua putus. Sedangkan Kompilasi Hukum Islam 
(KHI) mengaturnya dalam pasal 98 bahwa (1) Batas usia anak yang mampu berdiri sendiri atau dewasa adalah 21 tahun, sepanjang anak tersebut tidak memiliki cacat fisik maupun mental atau belum pernah melangsungkan perkawinan.

Orang tuanya mewakili anak tersebut mengenai segala perbuatan hukum di dalam dan di luar pengadilan. (3) Pengadilan Agama dapat menunjuk salah seorang kerabat terdekat yang mampu menunaikan kewajiban tersebut apabila kedua orang tuanya tidak mampu.

Kompilasi Hukum Islam Pasal 106 menjelaskan (1) Orang tua berkewajiban merawat dan mengembangkan harta anaknya yang belum dewasa atau di bawah pengampuan, dan tidak diperbolehkan memindahkan atau menggadaikannya kecuali karena keperluan yang mendesak jika kepentingan dan kemaslahatan anak itu menghendaki atau suatu kenyataan yang tidak dapat dihindarkan lagi. (2) Orang tua bertanggung jawab atas kerugian yang ditimbulkan karena kesalahan dan kelalaian dari kewajiban yang tersebut pada Ayat (1).

Untuk memelihara dan melindungi kepentingan anak, Undang-Undang Nomor 23 tahun 2002 tentang Perlindungan Anak Pasal 4 menjelaskan bahwa setiap anak berhak untuk dapat hidup, tumbuh, berkembang, dan berpartisipasi secara wajar sesuai dengan harkat dan martabat kemanusiaan, serta mendapat perlindungan dari kekerasan dan diskriminasi. Pasal 5 menjelaskan setiap anak berhak atas suatu nama sebagai identitas diri dan status kewarganegaraan, Pasal 6 Setiap anak berhak untuk beribadah menurut agamanya, berpikir, dan berekspresi sesuai dengan tingkat kecerdasan dan usianya, dalam bimbingan orang tua.

Hubungan anak dengan orang tuanya dijelaskan dalam Pasal 7 bahwa (1) Setiap anak berhak untuk mengetahui orang tuanya, dibesarkan, dan diasuh oleh orang tuanya sendiri. (2) Dalam hal karena suatu sebab orang tuanya tidak dapat menjamin tumbuh kembang anak, atau anak dalam keadaan terlantar maka anak tersebut berhak diasuh atau diangkat sebagai anak asuh atau anak angkat oleh orang lain sesuai dengan ketentuan peraturan perundangundangan yang berlaku.

Pemeliharaan tentang kesehatan anak dijelaskan dalam Pasal 8 Setiap anak berhak memperoleh pelayanan kesehatan dan jaminan sosial sesuai dengan kebutuhan fisik, mental, spiritual, dan sosial. Pasal 9, (1) Setiap anak berhak memperoleh pendidikan dan pengajaran dalam rangka pengembangan pribadinya dan tingkat kecerdasannya sesuai dengan minat dan bakatnya. (2) Selain hak anak sebagaimana dimaksud dalam ayat (1), khusus bagi anak yang menyandang cacat. juga berhak memperoleh pendidikan luar biasa, sedangkan bagi anak yang memiliki keunggulan juga berhak mendapatkan pendidikan khusus. 
Pasal 10 menyebutkan setiap anak berhak menyatakan dan didengar pendapatnya, menerima, mencari, dan memberikan informasi sesuai dengan tingkat kecerdasan dan usianya demi pengembangan dirinya sesuai dengan nilai-nilai kesusilaan dan kepatutan.

Pasal 11 Setiap anak berhak untuk beristirahat dan memanfaatkan waktu luang, bergaul dengan anak yang sebaya, bermain, berekreasi, dan berkreasi sesuai dengan minat, bakat, dan tingkat kecerdasannya demi pengembangan diri. Tentang anak cacat diatur dalam Pasal 12 Setiap anak yang menyandang cacat berhak memperoleh rehabilitasi, bantuan sosial, dan pemeliharaan taraf kesejahteraan sosial. Pasal 13 mengantur (1) Setiap anak selama dalam pengasuhan orang tua, wali, atau pihak lain mana pun yang bertanggung jawab atas pengasuhan, berhak mendapat perlindungan dari perlakuan:
a. diskriminasi;
b. eksploitasi, baik ekonomi maupun seksual;
c. penelantaran;
d. kekejaman, kekerasan, dan penganiayaan;
e. ketidakadilan; dan
f. perlakuan salah lainnya.

(2) Dalam hal orang tua, wali atau pengasuh anak melakukan segala bentuk perlakuan sebagaimana dimaksud dalam ayat (1), maka pelaku dikenakan pemberatan hukuman.

Pasal 14 menjelaskan Setiap anak berhak untuk diasuh oleh orang tuanya sendiri, kecuali jika ada alasan dan/atau aturan hukum yang sah menunjukkan bahwa pemisahan itu adalah demi kepentingan terbaik bagi anak dan merupakan pertimbangan terakhir.

Pasal 15 mengatur setiap anak berhak untuk memperoleh perlindungan dari:

a. penyalahgunaan dalam kegiatan politik;

b. pelibatan dalam sengketa bersenjata;

c. pelibatan dalam kerusuhan social

d. pelibatan dalam peristiwa yang mengandung unsur kekerasan; dan

e. pelibatan dalam peperangan

Pasal 16 menjelaskan tentang perlindungan anak dari tindakan kekerasan bahwa: (1) Setiap anak berhak memperoleh perlindungan dari sasaran penganiayaan, penyiksaan, atau penjatuhan hukuman yang tidak manusiawi. (2) Setiap anak berhak untuk memperoleh kebebasan sesuai dengan hukum. (3) Penangkapan, penahanan, atau tindak pidana penjara anak hanya dilakukan apabila sesuai dengan hukum yang berlaku dan hanya dapat dilakukan sebagai upaya terakhir. Pasal 17 (1) Setiap anak yang dirampas kebebasannya berhak untuk:

a. mendapatkan perlakuan secara manusiawi dan penempatannya dipisahkan dari orang dewasa;

b. memperoleh bantuan hukum atau bantuan lainnya secara efektif dalam setiap tahapan upaya hukum yang berlaku; dan 
c. membela diri dan memperoleh keadilan di depan pengadilan anak yang objektif dan tidak memihak dalam sidang tertutup untuk umum.

(2) Setiap anak yang menjadi korban atau pelaku kekerasan seksual atau yang berhadapan dengan hukum berhak dirahasiakan. Pasal 18 Setiap anak yang menjadi korban atau pelaku tindak pidana berhak mendapatkan bantuan hukum dan bantuan lainnya. Pasal 19 menjelaskan Setiap anak berkewajiban untuk:

a. menghormati orang tua, wali, dan guru;

b. mencintai keluarga, masyarakat, dan menyayangi teman

c. mencintai tanah air, bangsa, dan negara

d. menunaikan ibadah sesuai dengan ajaran agama

\section{Syarat-syarat hadhin}

Seorang hadhin (ibu asuh) yang menangani dan menyelenggarakan kepentingan anak kecil yang diasuhnya yaitu adanya kecukupan dan kecakapan yang memerlukan syarat-syarat tertentu. Jika syaratsyarat itu tidak terpenuhi satu saja maka gugurlah kebolehan menyelenggarakan hadhanah. Syaratsyarat itu adalah sebagai berikut:
a. Berakal sehat
b. Dewasa
c. Mampu mendidik
d. Amanah dan berbudi
e. Adil dalam artian menjalankan agama secara baik (Amir Syarifuddin, 2006: 329).

f. Islam (Q.S. An-Nisa' [4]: 141). g. Ibunya belum kawin lagi, jika si ibu telah kawin lagi dengan lakilaki lain maka hak hadhanahnya hilang (hasan. ditakhrij oleh Abud Dawud 2244 dan An-Nasa'i 3495).

h. Merdeka (Sayyid Sabiq, 1984)

i. Mampu mendidik, sehingga orang yang buta, sakit, terbelenggu dan hal-hal lain yang dapat membahayakan atau anak disiasiakan maka tidak berhak mengasuh anak.

4. Temuan Penelitian

Penentuan persyaratan seorang Hadhin dalam realitas keseharian pada masyarakat, sangat ditentukan dari kope ntesi yang dimiliki hadhin dan kondisi si anak apakah anak mempunyai kebutuhan khusus (disabiltas). Persyaratan seorang pengasuh tidak saja sekedar balingh berakal, beragama Islam, tetapi juga diiringi dengan kemampuannya dalam kopentensi keagmaan, sosial, hukum dan ekonomi. Sebab hadanah itu merupakan pekerjaan yang penuh tanggung jawab. Oleh sebab itu, seorang ibu yang mendapatkan ganguan jiwa atau gangguan ingatan tidak layak melakukan tugas hadhanah (Mujiono, 1996, th) menambahkan agar yang melakukan hadanah tidak mengidap penyakit menular. Hadhin harus mempunyai kemampuan dan kemauan untuk memelihara dan mendidik anak yang diasuh dan tidak terikat dengan sauatu pekerjaan yang bisa mengakibatkan tugas hadanah menajadi terlantar. Seorang yang melakukan hadhanah dapat dipercaya memegang amanah, orang yang rusak akhlaknya tidak dapat 
memberi contoh yang baik kepada anak yang diasuh, oleh kerena itu ia tidak layak melakukan tugas ini.

Pembahasan ini membahas empat kondisi yang ditemukan dalam masyarakat dan terdapat perbedaan pendapat para ulama dalam menetapkannya ada yang memilih pendapat pertama atau kedua dan peneliti menetapkan pendapat yang ketiga, berikut uraiannya:

a. Pendapat pertama hak hadhanah oleh ibu yang murtad pindah kepada ayah, karena ibu tidak memenuhi persyaratan sebagai hadhin yakni tidak Islam berdasarkan (Q.S. An-Nisa [4]: 141) ini pendapat Syafi'iyah. Dalam satu perkara yang ditetap oleh pengadilan Agama tebing tinngi sebagaimana yang di analisis oleh Satria Effendi (Satria Effendi, 2004: 167), keterangan perkaranya adalah bapak mengugat ibu untuk mengasuh anak, alasan pengugat ibu sianak masih kuliah, tidak dapat mengsuh langsung anak pengugat sehingga terpaksa tinggal dan diasuh orang tua tergugat yang memeluk agama Kristen Protestan. Anak pengugat lahir dari seorang ayah dan ibu beragama Islam dan sekarang mantan istrinya pindah agma sehingga ditakutkan anaknya menjadi pemeluk agama Kristen.

b. Pendapat kedua hak hadhanah oleh seorang ibu pindah kepada ayah bila ibu sebagai hadhin sibuk dengan aktivitas di luar rumah, artinya ibu tidak fokus dan banyak waktu memberikan pengasuhan kepada anaknya, sementara anaknya sangat dekat dengan ayahnya dan merasa nyaman tinggal dengan ayah. Alasan hakim (perkara No.0317/Pdt.G/2010/ PA. Plg. menetapkan ayah sebagai hadhin karena dua orang anak telah diasuh dengan baik oleh ayahnya. Hal ini mengutamakan kemaslahatan untuk anak dan mengabaikan hak hadhanah oleh ibunya.

c. Ketiga pendapat hadhanah pindah kepada ayah karena dia punya kemampuan kopentesi dalam pengasuhan anak, seperti berakhlak mulia, punya kopetensi dalam ilmu pendidikan dan kopetensi sosial. Serta dapat memberikan waktu yang cukup untuk pengasuhan anak. Pendapat ini sejalan dengan putusan hakim perkara nomor 0989/Pdt.G/2015/Pdg, hakim menetapkan hadhanah kepada tergugat ayah yang punya dua orang anak berumur 8 tahun dan 10 bulan, berdasarkan pertimbangan pengugat dan tergugat sama-sama telah menikah setelah perceraian dan mempunyai rumah tangga masing-masing. Dalam perkara ini disaat terjadi perselisihan istri meningalkan rumah dan anakanaknya, sehingga yang mengasuh anak adalah ayahnya. Hakim beralasan Pertama anak memiliki tingkat stabilitas mental 
yang berbeda dibandingkan denga orang dewasa. Anak lebih labil sehingga sepatutnya dihindarkan dari potensi perubahan kondisi atau keadaan yang bersifat ekstrim. Kemampuan anak untuk beradaptasi dengan lingkungan dan pola hidup yang baru tidak sebaik orang dewasa. Apabila anak sudah tumbuh secara wajar dan tidak terdapat ancaman yang berarti untuk tetap mempertahankan keadaan yang ada saat ini (anak tetap berada dalam pengasuhan ayahnya). Hakim berdalil dengan kaedah yang mengatakan artinya: menolak mafsadat lebih diutamakan dari menarik maslahat. Kedua, berdasarkan kitab qawaninus Syar'iyah halaman 104 menjelaskan apabila salah seorang dari orang tuanya pindah tempat, maka ayah lebih berhak untuk memelihara anaknya. Hakim juga menegaskan pertimbangan nya dengan Undang-Undang Nomor 1 Tahun 1974 Tentang Perkawinan Pasal 41 huruf a. Dalam perkara ini hakim mengutamakan kemaslahatan anak dari pada hak pengasuhan lebih diutamakan kepada ibu bardasar hadis yang mengutakan ibu sebgai hak hadhanah.

d. Keempat pendapat hadhanah pindah kepada ayah karena ibu telah meninggalkan dua orang anak yang berumur 3 tahun 7 bulan dan 1 tahun 4 bulan beserta termohon. Putusan hakim perkara
Nomor 0048/Pdt.G/2015/PA. Pdg. Pertimbangan hakim, pertama termohon sebagai ibu telah melalaikan kewajibannya selaku ibu bahkan untuk berkominikasi saja dengan anakanaknya tidak dihiraukan lagi. Serta tidak mencerminkan akhlak mulia salah satu syarat dari hadhin Kedua, perbuatan ibu (termohon) bertentangan dengan Undang Undang Nomor: 23 tahun 2002 tentang perlindungan anak yang telah diubah dengan Undang Undang Nomor: 35 tahun 2014 Pasal 26.

Analisis peneliti tentang empat kondisi di atas yang putusan pengadilan agama memberikan hak asuh (hadhanah) kepada ayah karena dia punya kemampuan kopentesi dalam pengasuhan anak, seperti berakhlak mulia, punya kopetensi dalam ilmu pendidikan dan kopetensi sosial bertanggung jawab dan mengutamakan kemaslahatan anak dari pada menetapkan hak ibu sebagai pengasuh. Bila dicermati Undang Undang Nomor: 23 tahun 2002 tentang perlindungan anak yang telah diubah dengan Undang Undang Nonor: 35 tahun 2014 Pasal 26 yang menyatakan: Ayat (1) Orang tua berkewajiban dan bertanggung jawab untuk: a. mengasuh, memelihara, mendidik, dan melindungi anak; $b$. menumbuhkembangkan anak sesuai dengan kemampuan, bakat, dan minatnya; c. mencegah terjadinya perkawinan pada usia anak-anak. Ketika ibu tidak mempunyai kemampuan untuk mengasuh 
anaknya seperti kondisi kasus di atas karena murtad, tidak baik moralnya, tidak bertanggungjawab dan lain sebagainya maka hak hadhanah lebih utama dipindahkan kepada ayah. Dalam pengasuhan anak yang lebih diutamakan adalah kemaslahatan anak dan kebutuhan tumbuh kembang anak.

Seseorang yang melakukan hadhanah harus bergama Islam. Seorang non muslim tidak berhak dan tidak boleh ditunjuk sebagai pengasuh. Tugas mengasuh termasuk ke dalamnya usaha mendidik anak menjadi muslim yang baik, dan hal itu menjadi kewajiban mutlak atas kedua orang tua. Para ahli fiqih mendasarkan kesimpulan tersebut pada ayat 6 surat At-Tahrim yang mengajarkan agar memelihara diri dan keluarga dari siksaan neraka. Untuk tujuan itu perlu pendidikan dan pengarahan dari waktu kecil. tujuan tersebut akan sulit terwujud bilamana yang mendampingi atau yang mengasuhnya bukan seorang muslim. Pada literatur-literatur hukum fiqih menunjukkan ketidaksepakatan para ahli hukum Islam terhadap syarat beragama Islam bagi yang akan melakukan hadanah. Satria mengungkapkan persyaratan untuk beragama Islam bagi yang melakukan hadanah adalah Imam Syafii. Lebih lengkap Satria mengungkapkan Ibnu Qasim, Mazhab Hambali, sebagian kalangan Hanafiyah dan Imam Muhammad Abu Zahrah tidak menysaratkan beragama Islam bagi yang melakukan hadhanah terhadap anak yang beragama Islam selagi anak itu belum mumayyiz (di bawah umur tujuh tahun). Menurut kalangan yang tidak mensyaratkan beragama Islam bagi pelaku hadhanah adalah hak hadhanah seorang ibu terhadap anaknya yang dilahirkan melalui pernikahan secara Islam tidak jadi gugur disebabkan ibu tidak beragama Islam, kecuali jika anak sudah mumayyiz. Dalam umur sebelum mumayyiz, seorang anak masih sangat membutuhkan kasih sayang ibu kandungnya, sebab ibu lebih mengerti dengan kebutuhannya. Dalam Pandangan ini tidak tampak kekhawatiran terpengaruhnya anak dalam umur tersebut kepada agama ibunya. Karena menurut mereka anak pada masa umur tersebut belum mengerti sama sekali masalah agama, kecuali jika diketahui adanya unsur kesengajaan seorang ibu untuk menyeret anaknya ke agamanya.

Satria Efendi mengutip pendapat Abu Zahra dalam kitab Al-ahwalasysyakhsiyyah bahwa hak hadhanah seseorang ibu yang nonmuslim terhadap anaknya yang muslim dan belum mumayyiz, baru menjadi gugur bilamana diketahui adanya tingkah laku atau kesengajaan si ibu untuk mempengaruhi atau menyeret anak itu kepada agama yang di peluknya. Dalam hal ini Satria menlihat memang ada perbedaan tentang syarat hak hadhanah tidak beragama Islam tapi berdasarkan analisis beliau terhadap putusan Pengadilan Agama Tebing Tinggi ada usaha yang dilakukan oleh Ibu untuk membabtis anaknya dan dalam persidangan tergugat juga tidak membantah. Dalam hal ini Satria 
Efendi setuju dengan putusan Pengadilan Agama Tebing Tinggi yang mengabulkan gugatan penggugat untuk mendapatkan hak asuh anak. Satria lebih cendrung pada pendapat Syafii yang menjadikan beragam Islam bagi yang melakukan hak hadhanah, ide dan dasar Satria Efendi lebih sesuai dengan tujuan syariat (maqashidal-syariah) dalam hal menjaga agama.

Hakim lebih mementingkan kemaslahatan anak dari pada berpedoman Kompilasi Hukum Islam Pasal 105 yang menyebutkan pemeliharaan anak yang belum mumayyiz atau berumur 12 tahun adalah ibunya. Hakim dalam memutuskan perkara tidak hanya sebagai corong Undang-undang, tetapi hakim boleh berijtihad dan melakukan contra legem yakni mengenyampingkan Pasal undangundang tertentu dan menetapkan putusan berdasarkan ijtihadnya sendiri dengan syarat hakim mampu mengemukakan dasar-dasar pertimbangan yang rasional dan mengujudkan kemaslahatan, bahwa pasal yang disingkirkan benar-benar bertentangan dengan kepentingan umum, kepatutan, peradaban dan kemanusiaan, sehingga bila pasal itu diterapkan akan menimbulkan keresahan dan ketidak patutan (Yahya Harahap, 1997: 449).

\section{PENUTUP}

Hasil pembahasan terhadap empat perkara yang diputuskan Pengadilan Agama yang menjadi objek penelitian memberikan hak asuh (hadhanah) kepada ayah karena ayah mempunyaiemampuan kopentesi dalam pengasuhan anak, seperti berakhlak mulia, punya kopetensi dalam ilmu pendidikan dan kopetensi sosial yang bertanggung jawab dan mengutamakan kemaslahatan anak dari pada menetapkan hak ibu sebagai pengasu Dalam kondisi ini ayah memenuhi syarat-syarat dari hadhin dibandingkan dengan ibu.

\section{DAFTAR KEPUSTAKAAN}

Az-zuhaily, Wahbah. 2011. Fiqih Islami wa Adillatuhu. (J. 10, Ed.). Jakarta: Gema Insani.

Effendi, Satria. 2004. Problematika Hukum Keluarga Islam Kontemporer. Jakarta: Prenada Media.

Hadis dalam Abud Dawud 2244 dan AnNasa'i 3495.

Harahap, Yahya. 1997. Beberapa Tinjauan Mengenai Sistrim Peradilan dan Penyelesaian Sengketa. Bandung: PT Citra Aditya Bakti.

PA Batusangkar. 2017. Laporan PA Batusangkar.

Sabiq, Sayyid. 1984. Fiqus Sunnah. Bairut: Dar al-Fikr.

Syarifuddin, Amir. 2006. Hukum Perkawinan di Indonesia antara fikih munakahat dan undang-undang Perkawinan.

Tribun news. 2017. Komnas PA Catat 63 Persen Dari 1.688 Pelaku Kekerasan Terhadap Anak Orang Dekat. Retrieved from http:/ / www.tribunnews.com/nasion al/2017/12/27/komnas-pa-catat-63- 
persen-dari-1688-pelaku-kekerasanterhadap-anak-orang-dekat
Undang-Undang Nomor 1 Tahun 1974 Tentang Perkawinan (1974).

Undang Undang Nomor: 23 tahun 2002 tentang perlindungan anak yang telah diubah dengan Undang Undang Nomor: 35 tahun 2014. 